\title{
Heterogeneity in Gastric Cancer: From Pure Morphology to Molecular Classifications
}

\author{
Irene Gullo ${ }^{a-d}$ Fátima Carneiro ${ }^{a-d}$ Carla Oliveira ${ }^{b-d}$ Gabriela M. Almeidac, d

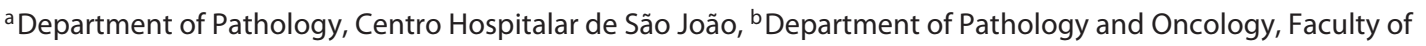 \\ Medicine of the University of Porto (FMUP), ' Institute of Molecular Pathology and Immunology of the University of \\ Porto (Ipatimup), and dInstitute for Research Innovation in Health (i3S), University of Porto, Porto, Portugal
}

\section{Keywords}

Gastric cancer · Stomach · Morphological heterogeneity ·

Molecular heterogeneity · Intratumour heterogeneity

\begin{abstract}
Gastric cancer (GC) represents a global health concern. Despite advances in prevention, diagnosis, and therapy, GC is still the third leading cause of cancer mortality worldwide, with more than 720,000 estimated deaths in 2012. Overall survival for advanced disease is about 1 year, a dismal prognosis that is partly due to the high levels of biological heterogeneity found in GC. Indeed, GC is a highly heterogeneous disease from morphological and molecular standpoints. The numerous histological and molecular classifications currently available reflect such heterogeneity. Although recent high-throughput studies cluster the molecular data obtained into subgroups with clinical relevance, we still need a practical, prognostic, and predictive classification system, integrating morphological and molecular features, towards the identification of novel therapeutic targets. It is noteworthy that GC heterogeneity encompasses not only interpatient variability (intertumour heterogeneity), but also variations within the same tumour (intratumour heterogeneity). The latter encompasses spatial heterogeneity (in different
\end{abstract}

tumour areas) and temporal heterogeneity (along progression from primary to recurrent and/or metastatic disease). In this review, we analyse the morphological, immunophenotypic, and molecular heterogeneity in GC as the basis for a better understanding of the disease, and discuss the practical implications for diagnostic pathology, prognostic evaluation, and precision therapy.

(c) 2017 S. Karger AG, Basel

\section{Introduction}

Gastric cancer (GC) constitutes an important health problem. It is the fifth most common cancer and the third leading cause of cancer mortality worldwide [1]. Despite a gradual decline of incidence and mortality in recent decades, and despite improvements in prevention, diagnosis, and therapeutic approaches, the burden remains high. Based on GLOBOCAN estimates, 952,000 GC cases were diagnosed in 2012, causing 723,000 deaths [1].

The high mortality of GC is mainly due to late diagnosis and poor response to the currently available therapeutic regimens. One of the reasons that may explain the poor clinical outcomes of GC therapy is the highly heterogeneous nature of this disease. Tumour heterogeneity can be

\section{KARGER}

(c) 2017 S. Karger AG, Basel 
due to genetic alterations, epigenetic events, interactions between tumour cells and the microenvironment, and also interactions between the different tumour cell clones/ populations within the tumour. Such heterogeneity involves geographical variations, macroscopic and microscopic features, as well as molecular alterations. Moreover, phenotypic and molecular diversity encompasses not only interpatient variations (intertumour heterogeneity), but also variations within the same tumour (intratumour heterogeneity; ITH). However, currently, few histopathological and/or molecular features are taken into account in the clinical management of GC patients. Adequate surgical resection, or endoscopic resection in selected early-stage tumours [2], are the mainstays of the curative approach. Fluoropyrimidine- and platinum-based chemotherapeutic regimens are recommended in the neoadjuvant or adjuvant setting, and as the first-line treatment in patients with advanced and unresectable GC. Overall, objective response rates to chemotherapy range from 20 to $40 \%$, indicating variable clinical responses, probably caused by underlying biological heterogeneity [3]. In addition to conventional chemotherapeutic regimens, targeted therapies, consisting of small molecules or monoclonal antibodies able to disrupt specific oncogenic pathways, have recently emerged as new therapeutic strategies. Based on phase III clinical trials, trastuzumab (anti-HER2; human epidermal growth factor receptor 2) [4] and ramucirumab (anti-VEGFR2; vascular endothelial growth factor receptor 2) [5, 6] monoclonal antibodies have recently been approved as clinically validated molecular targeted therapies in the treatment of advanced/metastatic GC. However, these therapies offer only a limited survival advantage of a few months (1.5-2.2 months) [4-6] and, to date, with the exception of HER2, there are no predictive biomarkers of tumour response to targeted therapies in GC [7]. Other biological agents (e.g., cetuximab and panitumumab, anti-EGFR monoclonal antibodies) have failed to demonstrate a survival benefit in GC $[8,9]$. Very recently, cancer immunotherapies, able to impair the cancer evasion from immune surveillance, have been explored. Phase II/III clinical trials with antibodies directed against CTLA-4 and PD-1/PD-L1 immune inhibitory checkpoints are currently ongoing in GC and are new attractive therapeutic strategies for GC patients [10-13].

Overall, more effective treatment options are urgently required for improving GC patient outcome. Since tumour plasticity and, both inter- and intratumour heterogeneity are reported as putative contributors to treatment failure, it is pivotal to study/understand GC heterogeneity in order to develop more effective therapeutic regimens that are able to target the heterogeneous tumour cell populations. Therefore, in this review article, we will discuss the inter- and intratumour heterogeneity of GC, from morphological and molecular standpoints, focusing on diagnostic, prognostic, and therapeutic implications.

\section{Morphological Heterogeneity of GC}

GC is very heterogeneous from the morphological standpoint. The large number of histopathological classifications proposed over the years testifies to the great variability of GC morphology. Moreover, it is worth pointing out that morphological ITH, i.e., the coexistence of different morphological components within the same tumour, is frequent, adding complexity to histological classifications and raising concerns about accuracy and reproducibility. Some of the histological classification schemes that have been proposed are those of Laurén (1965) [14], Nakamura (1968) [15], Ming (1977) [16], Goseki (1992) [17], Carneiro (1995) [18], Solcia (2009) [19], the World Health Organization (WHO; 2010) [20], and the Japanese Gastric Cancer Association (2011) [21] (Table 1). Figure 1 shows the variable histological patterns of GC, depicting the intertumour morphological heterogeneity.

Despite dating back to 1965, the Laurén classification [14], still remains widely accepted and used. It is based on a dichotomous scheme that distinguishes 2 main types: intestinal GC, forming tubular or papillary structures, and diffuse GC, characterised by poorly cohesive and infiltrative tumour cells that may or may not have a signet ring cell (SRC) morphology. The group of GCs which do not fit within these 2 major types encompasses mixed and indeterminate subtypes. Intestinal and diffuse GCs are clinically relevant subtypes, exhibiting distinct epidemiological profiles, histogenesis, clinicopathological and molecular features, as well as biological behaviour.

Intestinal GC most commonly occurs in elderly patients, mainly males, whereas diffuse GC is more common in young patients, mainly females. Both subtypes share environmental risk factors (e.g., Helicobacter pylori and Epstein-Barr virus infection, dietary habits, smoking); however, the diffuse GC pathogenesis is less well understood and presents a hereditary component. As a result, intestinal GC is more common in high-risk regions and is steadily decreasing in incidence, whereas diffuse GC is more common in low-risk areas and has a quite stable incidence $[22,23]$. Moreover, cohesive versus noncohesive morphological features probably correlate with 
Table 1. Heterogeneity of histopathological classification systems in gastric cancer

\begin{tabular}{|c|c|c|c|c|c|c|}
\hline \multirow[t]{2}{*}{ Diffuse } & \multirow[t]{2}{*}{$\begin{array}{l}\text { Isolated } \\
\text { cell }\end{array}$} & $\begin{array}{l}\text { Poorly cohesive, } \\
\text { SRC phenotype }\end{array}$ & SRC carcinoma & $\begin{array}{l}\text { Undifferentiated } \\
\text { type }\end{array}$ & $\begin{array}{l}\text { IV. Poor tubular } \\
\text { differentiation, mucin } \\
\text { rich }\end{array}$ & Diffuse, ordinary subtype \\
\hline & & $\begin{array}{l}\text { Poorly cohesive, } \\
\text { other cell types }\end{array}$ & $\begin{array}{l}\text { Poorly differentiated, non- } \\
\text { solid type }\end{array}$ & & $\begin{array}{l}\text { III. Poor tubular } \\
\text { differentiation, mucin } \\
\text { poor }\end{array}$ & $\begin{array}{l}\text { Diffuse, low-grade } \\
\text { desmoplastic subtype }\end{array}$ \\
\hline \multirow[t]{2}{*}{$\begin{array}{l}\text { Indeter- } \\
\text { minate }\end{array}$} & Solid & Undifferentiated & $\begin{array}{l}\text { Poorly differentiated, solid } \\
\text { type }\end{array}$ & $\begin{array}{l}\text { Undifferentiated } \\
\text { type }\end{array}$ & $\begin{array}{l}\text { III. Poor tubular } \\
\text { differentiation, mucin } \\
\text { poor }\end{array}$ & Anaplastic \\
\hline & $\begin{array}{l}\text { Rare } \\
\text { variants }\end{array}$ & Rare variants & & & & High lymphoid response \\
\hline
\end{tabular}

SRC, signet ring cell.

the different tumour spreading patterns: while intestinal GC tends to metastasize hematogenously to the liver, diffuse GC usually disseminates through peritoneal surfaces [20]. Finally, based on the original report by Laurén et al. [14] and more recent studies [24-26], diffuse GC appears to behave more aggressively than intestinal GC and has been identified as an independent poor prognostic factor.

In 1995, Carneiro et al. [18] further elucidated the biological features and prognostic significance of mixed GC. Mixed GC, defined by a dual pattern of differentiation glandular/solid (intestinal) and isolated-cell carcinoma (diffuse) - carried, in a multivariate analysis, significantly worse prognosis than the 2 main types of the Laurén classification [18, 27]. As further proof, several authors demonstrated that mixed GCs display more aggressive features than "pure" intestinal and diffuse GCs, including larger tumour size, deeper invasion, lymphatic invasion, and lymph node metastases [27-31]. Interestingly, mixed GC shows a dual metastatic pattern (hematogenous metastases and peritoneal dissemination with lymph node metastases), suggesting a cumulative effect of the adverse behaviours of intestinal and diffuse-type GC [32]. Therefore, the recognition and report of this mixed subtype is essential and is currently included in the 2010 WHO classification [20].
The WHO classification [20] is based on the recognition of specific histological patterns, also observed in other segments of the gastrointestinal tract, providing a unifying approach. However, this classification does not show significant relationships with epidemiological, clinicopathological, prognostic, or molecular characteristics. The WHO classification describes tubular and papillary adenocarcinomas (corresponding to the Laurén intestinal subtype), mucinous adenocarcinoma, poorly cohesive carcinoma (corresponding to the Laurén diffuse subtype), mixed carcinoma, and other rare histological variants, with the latter accounting for a small percentage of cases (about 5\%). The WHO bluebook dedicates an entire chapter to hereditary diffuse gastric cancer (HDGC), the first hereditary syndrome identified in the stomach. HDGC is an autosomal dominant cancer-susceptibility syndrome that accounts for $1-3 \%$ of familial GCs and is characterised by a diffuse morphology and specific biological behaviour [33]. Heterozygous germline mutations have been recurrently found in the E-cadherin gene $(C D H 1$, in $28-40 \%$ of cases) $[34,35]$ and $\alpha$-E-catenin gene (CTNNA1) $[35,36]$, highlighting the inactivation of these two genes as the cause of HDGC. Recently, potentially deleterious mutations have been identified in the BRCA2, STK11, SDHB, PRSS1, ATM, MSR1, and PALB2 
Fig. 1. Morphological heterogeneity in GC. Several histological patterns are represented according to the WHO classification. a Tubular adenocarcinoma, well differentiated. HE. Original magnification $\times 100$. b Papillary adenocarcinoma, well differentiated. HE. Original magnification $\times 40$. c Poorly cohesive carcinoma, composed of SRCs (left side) and poorly cohesive, pleomorphic cells (right side). HE. Original magnification $\times 400$. d Mixed carcinoma, displaying glandular/intestinal (left side) and poorly cohesive/diffuse elements (right side). HE. Original magnification $\times 200$. e Mucinous adenocarcinoma, with extracellular mucinous pools. HE. Original magnification $\times 40$. $\mathbf{f}$ Undifferentiated carcinoma. HE. Original magnification $\times 100$. g Hepatoid carcinoma, a rare histological variant characterised by large and polygonal cells with an abundant cytoplasm, resembling hepatocellular carcinoma. HE. Original magnification $\times 200$. Intracytoplasmic hyaline and periodic acid-Schiff-positive, diastase-resistant (PASD) globules can be observed $(\times 400$; arrowheads and inset left), that display $a$-fetoprotein $(\alpha \mathrm{FP})$ immunoreactivity $(\times 400$; aFP IHC, inset right). h GC with lymphoid stroma, a rare histological variant in which the tumour cells are widely separated by an abundant lymphoid stroma. HE. Original magnification $\times 100$.
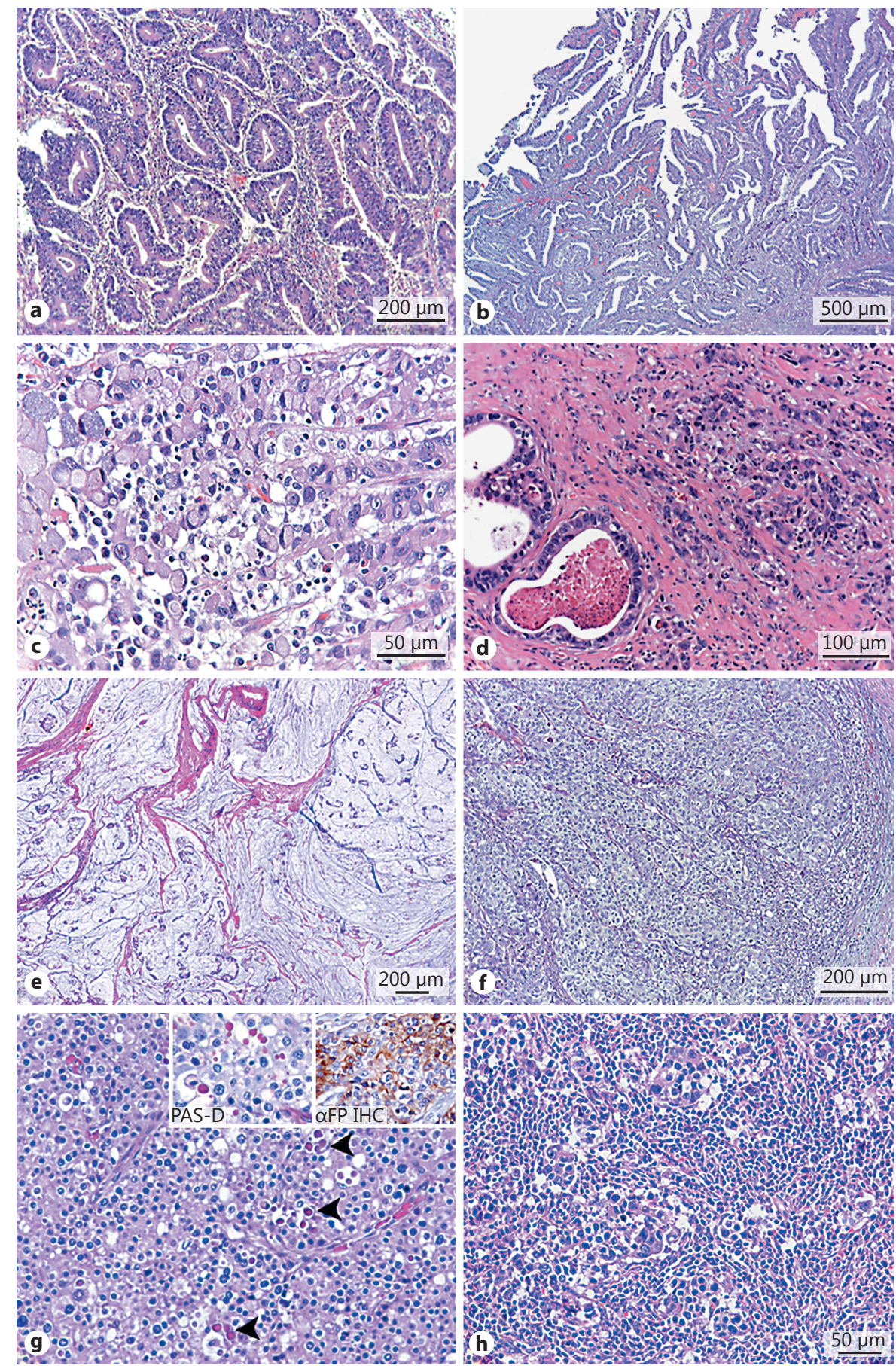

genes in HDGC families [35], albeit in a very small fraction of cases, and still with uncertain significance. The study of prophylactic gastrectomy specimens from asymptomatic $\mathrm{CDH} 1$ mutation carriers led to the identification, in a very high proportion of cases, of multiple intramucosal cancer foci (pT1a), composed of bona fide SRCs, which are smaller at the neck zone and progres- sively enlarge towards the surface of gastric mucosa [20, 37]. Precursor intraepithelial lesions (pTis), which are rare and hard to identify, encompass in situ SRC carcinoma and a pagetoid spread of SRCs [20,38]. In a recent study [39], we described the variable morphological spectrum of precursor, early, and advanced lesions in HDGC. We found that early lesions (pTis and pT1a) display an 
"indolent phenotype," composed of typical SRCs, while advanced HDGC ( $\mathrm{pT}>1)$ is characterised by an "aggressive phenotype," with a mixture of SRCs and pleomorphic, bizarre, and diffusely infiltrative cells. Moreover, the "aggressive phenotype" was statistically associated with the Ki-67 high-proliferation index and p53 expression. Hence, the heterogeneous nature of GC in the hereditary setting may help to define prognostic markers of progression from indolent to widely invasive carcinoma.

Among the other histopathological classification systems, those proposed by Goseki et al. [40, 41] and Solcia et al. [42] are important predictors of outcome. The Goseki histological grading system [17] identifies four categories combining the degree of tubular/glandular differentiation and the amount of mucus in the cytoplasm. More recently, Solcia et al. [19] proposed a 3-tiered prognostic classification based on histological, clinicopathological, and molecular parameters (Table 1).

In addition to classifications based on tumour morphology, GC can also be classified by immunohistochemistry (IHC) on the basis of lineage-differentiation markers. MUC5AC and TTF1 are markers of surface gastric epithelium, MUC6 and TTF2 represent markers of mucous neck cells or pyloric glands, while MUC2, CD10, and CDX2 are intestinal differentiation biomarkers. According to their expression, four GC immunophenotypes have been recognised: the intestinal (expressing MUC2, CD10, CDX2), gastric (expressing MUC5AC/TTF1 and/ or MUC6/TTF2), hybrid (expressing intestinal and gastric markers), and null phenotype [43-46]. These phenotypes have also been recognised in GC precursor lesions [47-49]. Several authors have found differential genetic and epigenetic alterations in gastric versus intestinal phenotypes [50,51], although the association with specific clinicopathological features and the prognosis is still conflicting $[45,51]$. During GC progression, a phenotypic switch may occur from gastric to intestinal differentiation [45]; moreover, some authors hypothesise that GC with a gastric phenotype may also progress to poorly differentiated GC $[44,47]$.

\section{Moving towards Molecular Subtyping and Precision Medicine}

A detailed characterisation of the GC molecular landscape is pivotal for the understanding of the biological behaviour of the disease, the identification of new molecular markers and, ultimately, for the improvement of diagnostic and therapeutic strategies. Gene mutations, somatic copy number alterations, epigenetic changes, transcriptional changes, etc., have been studied over the years [52], revealing the extraordinary molecular heterogeneity of GC. Indeed, there is an urgent need to decipher such complex heterogeneity into clinical and biological homogenous subgroups.

With the recent advent of next-generation sequencing, several groups [3,53-55] have analysed GC molecular alterations at high resolution, using various high-throughput platforms. These studies attempted to achieve an integrated molecular classification scheme, clustering the comprehensive molecular data obtained into subgroups with different molecular signatures and clinical phenotypes (Table 2).

Transcriptomic technologies have also been used to identify gene expression signatures with clinical relevance. A study by Tan et al. [3] started from GC cell lines to identify two "intrinsic" GC subtypes based on gene expressions (G-INT and G-DIF) that, when applied in GC samples, correlated with the Laurén classification, surviv$\mathrm{al}$, and response to chemotherapy. These gene expression signatures were further analysed in 248 GC specimens by Lei et al. [53] (Singapore-Duke group), leading to the identification of three subtypes that show differences in molecular/genomic features, morphology, "carcinogenic" pathways, and response to therapy. These groups are: (1) the mesenchymal subtype, enriched with diffuse GCs and characterised by cancer stem cell and epithelial-tomesenchymal transition (EMT) properties; (2) the proliferative subtype, with high levels of TP53 mutations, genomic instability, and activation of oncogenic pathways; and (3) the metabolic subtype, overexpressing genes that are normally expressed in gastric mucosa. Proliferative and metabolic subtypes frequently correspond to the Laurén intestinal type. More recently, Das et al. [56] confirmed similar results using NanoString nCounter technology in 54 formalin-fixed and paraffin-embedded GC tissues. Their study further characterised the expression profiles of mesenchymal, proliferative, and metabolic subtypes and identified new biomarkers of response to mTOR inhibitors (RAD001), namely the overexpression of MMP9 and BRCA2.

The landmark study of GC molecular-based stratification was carried out by The Cancer Genome Atlas (TCGA) research network [54], which proposed a fourtiered molecular classification that identifies: (1) EpsteinBarr virus-positive (EBV+) GC, characterised by recurrent PIK3CA mutations, frequent JAK2 and PD-L1 amplification, and a high level of DNA hypermethylation, as previously reported [57]; (2) GC with microsatellite in- 
Table 2. Molecular classifications of GC and their therapeutic implications

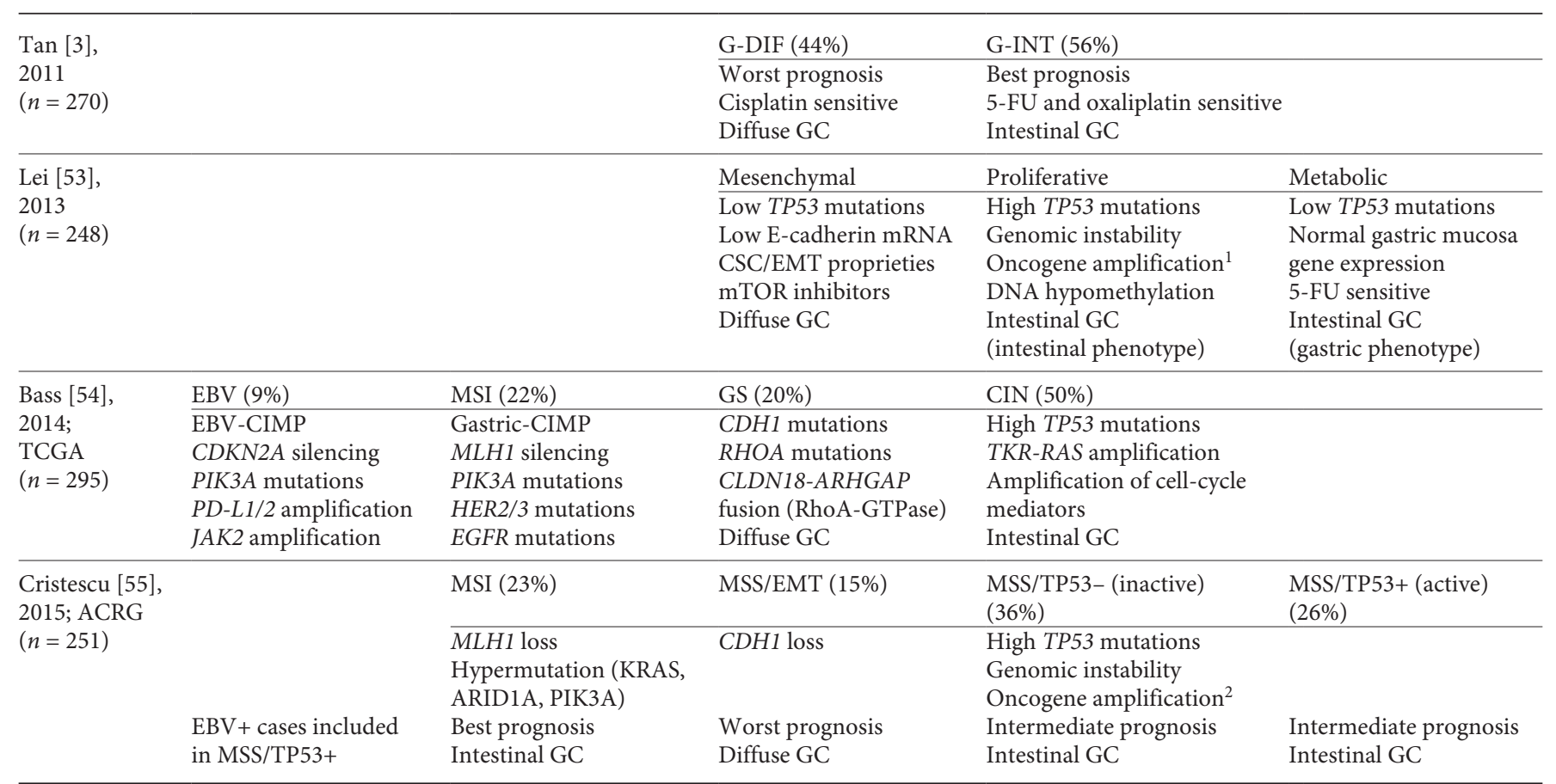

GC, gastric cancer; TCGA, The Cancer Genome Atlas; ACRG, Asian Cancer Research Group; 5-FU, fluorouracil; CSC, cancer stem cell; EMT, epithelial-to-mesenchymal transition; EBV, Epstein-Barr virus; CIMP, CpG island methylation phenotype; MSI, microsatellite instability; GS, genomically stable; CIN, chromosomal instability; TKR, tyrosine kinase receptors; MSS, microsatellite stable.

${ }^{1}$ ERBB2, CCNE1, MYC, and KRAS.

${ }^{2}$ ERBB2, EGFR, CCNE1, CCND1, MDM2, ROBO2, GATA6, and MYC.

stability (MSI-high) characterised by DNA hypermethylation and $M L H 1$ silencing; (3) genomically stable GC, associated with a diffuse morphology and recurrent $\mathrm{CDH} 1$ and $R H O A$ events, as confirmed by previous studies [5860]; and (4) GC with chromosomal instability (CIN), exhibiting intestinal morphology, a high number of TP53 mutations, and amplifications of tyrosine kinase receptors (TKR).

$\mathrm{EBV}+$ and MSI-high GCs are of particular interest. Morphologically, they are associated with prominent immune infiltrate [19] and frequently display the features of GC with lymphoid stroma [61-65]. There is growing evidence for the possibility of using PD-1/PD-L1 immune checkpoint inhibitors in these two molecular subtypes of GC, based on the following evidence: $P D-L 1$ amplification is frequent in EBV+ GC [54], and a recent study on colorectal, endometrial, small bowel, and gastric carcinoma cancer proved that MSI-high tumours treated with pembrolizumab (an anti-PD-1 monoclonal antibody) are associated with a higher rate of response and disease control compared to microsatellite stable (MSS) tumours
(ClinicalTrials.gov identifier: NCT01876511) [66]. Phase II clinical trials correlating response to pembrolizumab and molecular subtypes are currently ongoing in advanced GC (ClinicalTrials.gov identifier: NCT02589496). Several studies have demonstrated that PD-L1 immunoexpression is heterogeneous in GC, as in other tumour models. PD-L1 overexpression is associated with high densities of $\mathrm{CD} 3+$ and CD8+ tumour-infiltrating lymphocytes [67-69], GC with lymphoid stroma morphology [70], and both an EBV+ and MSI-high molecular status $[69,71-74]$. However, the correlation with $P D-L 1$ amplification, prognosis, and response to targeted immunotherapies is still debated and deserves further study.

Finally, The Asian Cancer Research Group (ACRG) described four molecular subtypes with distinct prognostic impacts [55]: (1) MSI-high tumours, with an intestinal morphology and the best prognosis as previously described [75]; (2) MSS/EMT GC, with a diffuse morphology and the worst prognosis; and (3 and 4) MSS adenocarcinomas, with no EMT signature, either TP53-active (MSS/TP53+) or inactive (MSS/TP53-), and with an in- 
termediate prognosis. The MSS/TP53- subtype (which roughly corresponds to the proliferative and CIN subtypes) is frequent (36-50\% of GCs) and harbours genomic amplifications of TKR and/or RAS, which are in use or potential therapeutic targets. In keeping with a previous study by Deng et al. [76], the ACRG found that TKR and RAS amplifications tended to be mutually exclusive, emphasising GC intertumour heterogeneity and the importance of investigating molecular alterations for targeted therapy.

As shown in Table 2, the three molecular classifications overlap only partially, highlighting the need for a consensual classification that may serve as a roadmap for patient stratification for prognostic evaluation and targeted therapy, in the era of precision medicine.

The tumour morphology may provide further insights into tumour biology and should be used as a frame for the identification of clinically relevant subgroups, as the backbone for building algorithms for directed and costeffective molecular characterisation of GC. However, few correlation studies of morphological classification and molecular characteristics have been carried out $[77,78]$ and pathologists should be aware of their pivotal role in this field. In-depth studies combining molecular features with histopathological and IHC profiles may reveal interesting associations and are currently feasible, thanks to new molecular profiling technologies, generating accurate molecular information from formalin-fixed and paraffin-embedded tissues [56, 79]. On this note, Setia et al. [80] have recently proposed a practical algorithm based on IHC and in situ hybridisation techniques currently available in routine diagnostic practice. In their study, the authors accomplished to translate different molecular subgroups into specific immunophenotypes with prognostic and predictive significance.

\section{Adding Further Complexity: ITH}

The phenotypic and molecular heterogeneity of GC encompasses not only intertumour heterogeneity, as discussed above, but also ITH. ITH has been described as a new hallmark of cancer, which enables tumour cells to self-organise, invade, metastasise, and develop drug-resistance, through mechanisms of Darwinian selection and clonal evolution [81, 82]. ITH includes variability of different clones within the same tumour (spatial heterogeneity) [83], between primary tumour and recurrent disease (temporal heterogeneity), and between primary tumour and different metastatic sites. Such a degree of
ITH is predicted to have important implications in tumour diagnosis/classification, prognosis, and therapeutic resistance [84]. Assuming that every tumour is a heterogeneous entity, the collection of a limited number of biopsy samples raises important issues regarding the representativeness of the different populations in the overall tumour. This common lack of adequate sampling affect the correct evaluation of predictive biomarkers (e.g., HER2 expression) and even the histological diagnosis [85].

Mixed GC is the prototype of morphological ITH, as it is composed, by definition, of different histological patterns within the same tumour [20]. Glandular/intestinal and isolated-cell/diffuse components considerably vary in percentage, as well as in distribution, since the two components may be intermingled, adjacent, or completely separated $[18,86]$. The recognition of this morphological entity is important, as it carries a bad prognosis compared to intestinal and diffuse GC (see Morphological Heterogeneity of GC, above). However, previous studies have shown that preoperative endoscopic biopsies have a limited value in predicting the presence of both components $[29,31,87]$. This is a clear example of how ITH may limit the correct pathological diagnosis and patient prognostic evaluation. The characterisation of molecular alterations underlying the two histotypes in mixed GC is of great interest and several authors have addressed this question. Machado et al. [88] demonstrated that inactivating $\mathrm{E}$-cadherin somatic mutations were almost restricted to the diffuse component of mixed GC, providing a genetic basis for the phenotypic divergence of this type of GC. The finding that IHC expression of adhesion molecules (E-cadherin, $\alpha$-catenin, $\beta$-catenin, $\gamma$-catenin) is more frequently preserved in the intestinal than diffuse component $[30,89]$ supports this hypothesis. Interestingly, some authors disclosed that the two components of mixed GC display similar DNA copy changes and CpG island hypermethylation status $[90,91]$. Particularly, the two components of mixed GC have a higher number of methylated genes than "pure" diffuse and intestinal GC [91]. All these findings are in favour of a clonal origin of mixed GC and suggest that the diffuse component may emerge during the progression of some GCs, due to the occurrence of E-cadherin somatic mutations. Further studies are still required for a better understanding of other molecular events underlying the dual phenotypic differentiation of mixed GC.

HER2 is a transmembrane TKR of the epidermal growth factor receptor (EGFR) superfamily that regulates cell proliferation, survival, differentiation, migration, 

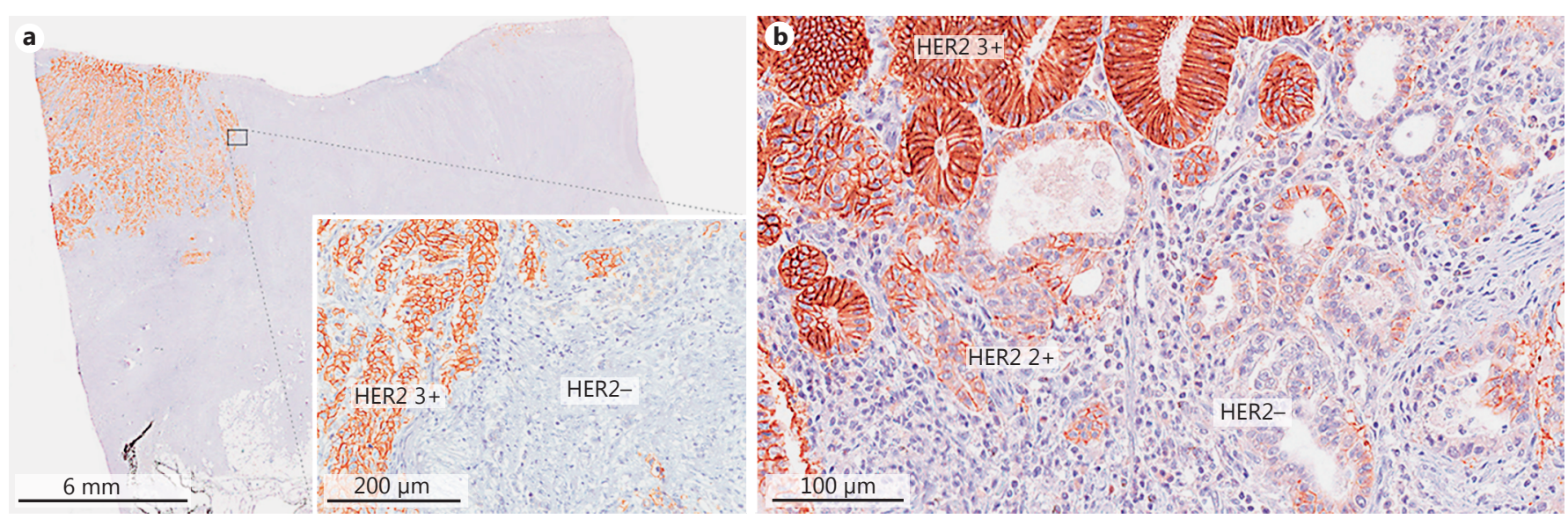

Fig. 2. Spatial ITH of HER2 expression in GC. Both images represent well-differentiated tubular adenocarcinoma, with variable HER2 immunoreactivity between the tumour clones, from strong and complete membranous staining to weak and incomplete membranous staining. HER2 IHC, low magnification (a), ×100 magnification (inset), and $\times 200$ magnification $(\mathbf{b})$.

and other cancer-relevant cellular responses. In contrast to other HER family members, HER2 can dimerise and activate downstream effectors without ligand binding. Trastuzumab, an anti-HER2 monoclonal antibody, inhibits HER2 signalling, preventing the activation of the intracellular tyrosine kinase domain [92]. In 2010, the phase III ToGA (trastuzumab for GC) trial (ClinicalTrials.gov identifier: NCT01041404) demonstrated a significant improvement in response rate, progression-free survival, and overall survival with the addition of trastuzumab to chemotherapy compared with chemotherapy alone, in prestratified patients with HER2-positive GC/ gastroesophageal junction cancer (GEJC) [4]. Since then, the use of trastuzumab with conventional chemotherapy has been approved by the US Food and Drug Administration (FDA) and the European Medicines Agency (EMEA) as first line therapy in advanced and metastatic HER2positive GC and GEJC patients. An HER2-positive status, evaluated by $\mathrm{IHC}(3+)$ and/or fluorescence in situ hybridization (HER2+/FISH+), is predictive of the patient response to trastuzumab-based treatment. Overall, HER2 overexpression is observed in $10-38 \%$ of GCs $[8,77,93-$ 100]. Accurate testing for a HER2-positive status is, hence, mandatory to identify patients who will likely respond to this targeted treatment.

One major problem in this context is the heterogeneity of HER2 expression/amplification. Indeed, HER2 status varies across tumour locations (proximal GC and GEJC are more frequently positive $[4,77,100])$, histological subtypes (the HER2-positive rate is higher in intestinal compared to diffuse GC $[4,101-111])$, and molecular classifications (proliferative, CIN, MSS/TP53- and MSI GC are molecular clusters more frequently associated with HER2 amplification [53-55, 80, 112]). Regarding mixed GC, some authors found that HER2 expression was restricted to the intestinal component [105], while others observed HER2 expression in both intestinal and diffuse components, in keeping with the hypothesis of clonal origin [107]. However, these studies evaluated only 4 and 2 mixed GCs, respectively, and further studies are necessary to clarify this issue.

Several authors have described ITH of HER2 expression in GC/GEJC. The extent of spatial heterogeneity of HER2 expression within primary tumours varies widely across studies, from 5 to $69 \%$ [94, 95, 106, 113-116]. These discrepancies can be explained by the lack of established criteria to evaluate and define HER2 ITH [117]. An interesting study indicated that HER 2 expression is more frequent in the luminal tumour layers than deep ones and in the lateral regions compared to the central zone [118]. Moreover, HER2 ITH between primary tumours and metastatic sites, both lymph node $[115,119,120]$ and hematogenous metastases [120-123], has been described, varying from 1 to $14 \%$. Figure 2 shows the spatial ITH of HER2 expression in GC.

The heterogeneous expression of HER2 in GC/GEJC has several implications. First, it is one of the putative mechanisms that attenuate the response to trastuzumabbased targeted therapy, explaining the limited survival advantage described in the ToGA trial [4] and the devel- 
opment of drug resistance [8]. Second, it can explain the controversial prognostic significance of HER2 status in GC/GEJC. In fact, while some studies showed that an HER2-positive status is associated with a worse prognosis and shorter survival $[93,98,102,110,124,125]$, others reported no prognostic value $[103,106,107,115,126-$ 129]. Third, HER 2 heterogeneity constitutes a real challenge to render a correct and reproducible evaluation of the biomarker. For instance, because heterogeneity and incomplete membranous immunoreactivity of HER2 staining are frequent in GC/GEJC, pathologists had to develop a distinct HER2 scoring system, different from that used in breast cancer $[94,124,130]$. Another interesting problem is that of sampling errors, as HER2 expression evaluated in a portion of the tumour might not be representative of the HER2 status in the whole tumour. On this point, several authors have shown that the analysis of more than 1 tumour section increases the HER2-positive detection rate by $5-10 \%[111,117,131,132]$. With regard to HER2 status in matched biopsy and resection specimens, various authors reported a high concordance rate, ranging from 74 to $96 \%[111,113,115,116,133,134]$. Among the discordant cases, HER2 ITH may play an important role, highlighting the necessity of performing a relatively high number of endoscopic biopsies. Several studies, based on a comparative analysis between surgical resection specimens and endoscopic or virtual biopsies, recommended a minimum of $4-5$ biopsies, preferentially from the proximal (oral part of the tumour), for reliable HER2 assessment $[118,135,136]$.

To summarise, these findings show the importance of characterising HER2 ITH for guiding pathological analysis and clinical decisions, for example choosing one or more blocks with the greatest amount of intestinal and well-differentiated tumour for HER2 assessment, considering the repetition of HER2 testing in recurrent/metastatic disease, and performing multiple biopsies preferentially from the oral portion of the tumour when only biopsy samples are available.

\section{Conclusions}

GC is a heterogeneous disease from a histological and molecular standpoint. The current diagnostic reference, guiding clinical decisions, is still based on a histopathological evaluation. Advances in molecular characterisation have recently offered deeper insights into the heterogeneous nature of this disease and have highlighted the possibility of recognising molecular targets of therapy, and creating more homogenous subgroups that may guide clinical decisions.

However, further studies are still needed, especially with respect to ITH. For instance, the understanding of molecular data in the frame of morphological/architectural information may be useful to better characterise spatial ITH, delineating the clonal evolution, the behaviour, and the relationship of different subclones, to better explain the prognosis and response to therapy and, ultimately, to build algorithms for precise and cost-effective molecular characterisation. Moreover, studying ITH, not only within primary tumours, but also in metastatic sites, will be pivotal for providing possible therapeutic solutions for advanced/metastatic disease.

\section{Acknowledgments}

Ipatimup integrates the i3S Research Unit, which is partially supported by FCT, the Portuguese Foundation for Science and Technology.

We would like to thank the support of the following entities and projects: (1) DOCnet (NORTE-01-0145-FEDER-000003), supported by Norte Portugal Regional Programme (NORTE 2020), under the PORTUGAL 2020 Partnership Agreement, through the European Regional Development Fund (ERDF); (2) FEDER Fundo Europeu de Desenvolvimento regional funds through the COMPETE 2020 - Operational Programme for Competitiveness and Internationalization (POCI), Portugal 2020, and Portuguese funds through FCT - Foundation for Science and Technology/ Ministério da Ciência, Tecnologia e Inovação in the framework of the project "Institute for Research and Innovation in Health Sciences" (POCI-01-0145-FEDER-007274); (3) NORTE-01-0145FEDER-000029, supported by the Norte Portugal Regional Programme (NORTE 2020), under the PORTUGAL 2020 Partnership Agreement, through the ERDF; research line 2 - project 2, "Mapping genetic and phenotypic heterogeneity in HER2-positive cancers to anticipate and counteract resistance phenotypes"; (4) salary support to G.M.A. (POPH - QREN type 4.2, European Social Fund and Portuguese Ministry of Science and Technology [MCTES], Contrato Programa no âmbito do Programa Investigador FCT 2013, IF/00615/2013).

We thank Luca Mastracci and Federica Grillo, from the Faculty of Medicine of the University of Genoa, Italy, for their contribution in the selection of images representative of HER2 intratumour heterogeneity.

\section{Disclosure Statement}

The authors have no competing interests to declare.
58

Pathobiology 2018;85:50-63 DOI: $10.1159 / 000473881$
Gullo/Carneiro/Oliveira/Almeida 


\section{References}

1 Ferlay J, Soerjomataram I, Ervik M, Dikshit R, Eser S, Mathers C, Rebelo M, Parkin DM, Forman D, Bray F: GLOBOCAN 2012 v1.0, Cancer Incidence and Mortality Worldwide: IARC CancerBase No. 11. Lyon, International Agency for Research on Cancer, 2013. http://globocan.iarc.fr (accessed October 22, 2016).

2 Smyth EC, Verheij M, Allum W, Cunningham D, Cervantes A, Arnold D: Gastric cancer: ESMO Clinical Practice Guidelines for diagnosis, treatment and follow-up. Ann Oncol 2016;27(suppl 5):v38-v49.

3 Tan IB, Ivanova T, Lim KH, Ong CW, Deng $\mathrm{N}$, Lee J, Tan SH, Wu J, Lee MH, Ooi CH, Rha SY, Wong WK, Boussioutas A, Yeoh KG, So J, Yong WP, Tsuburaya A, Grabsch H, Toh HC, Rozen S, Cheong JH, Noh SH, Wan WK, Ajani JA, Lee JS, Tellez MS, Tan P: Intrinsic subtypes of gastric cancer, based on gene expression pattern, predict survival and respond differently to chemotherapy. Gastroenterology 2011;141:476-485.

4 Bang YJ, van Cutsem E, Feyereislova A, Chung HC, Shen L, Sawaki A, Lordick F, Ohtsu A, Omuro Y, Satoh T, Aprile G, Kulikov E, Hill J, Lehle M, Ruschoff J, Kang YK: Trastuzumab in combination with chemotherapy versus chemotherapy alone for treatment of HER2-positive advanced gastric or gastro-oesophageal junction cancer (ToGA): a phase 3, open-label, randomised controlled trial. Lancet (London) 2010;376:687-697.

5 Fuchs CS, Tomasek J, Yong CJ, Dumitru F, Passalacqua R, Goswami C, Safran H, dos Santos LV, Aprile G, Ferry DR, Melichar B, Tehfe M, Topuzov E, Zalcberg JR, Chau I, Campbell W, Sivanandan C, Pikiel J, Koshiji M, Hsu Y, Liepa AM, Gao L, Schwartz JD, Tabernero J: Ramucirumab monotherapy for previously treated advanced gastric or gastro-oesophageal junction adenocarcinoma (REGARD): an international, randomised, multicentre, placebo-controlled, phase 3 trial. Lancet (London) 2014;383:31-39.

6 Wilke H, Muro K, Van Cutsem E, Oh SC, Bodoky G, Shimada Y, Hironaka S, Sugimoto N, Lipatov O, Kim TY, Cunningham D, Rougier P, Komatsu Y, Ajani J, Emig M, Carlesi R, Ferry D, Chandrawansa K, Schwartz JD, Ohtsu A: Ramucirumab plus paclitaxel versus placebo plus paclitaxel in patients with previously treated advanced gastric or gastro-oesophageal junction adenocarcinoma (RAINBOW): a double-blind, randomised phase 3 trial. Lancet Oncol 2014;15:1224-1235.

7 Fuchs CS, Tabernero J, Tomasek J, Chau I, Melichar B, Safran H, Tehfe MA, Filip D, Topuzov E, Schlittler L, Udrea AA, Campbell W, Brincat S, Emig M, Melemed SA, Hozak RR, Ferry D, Caldwell CW, Ajani JA: Biomarker analyses in REGARD gastric/GEJ carcinoma patients treated with VEGFR2-targeted antibody ramucirumab. Br J Cancer 2016; 115:974-982.
8 Lordick F, Janjigian YY: Clinical impact of tumour biology in the management of gastroesophageal cancer. Nat Rev Clin Oncol 2016; 13:348-360.

9 Lordick F, Kang YK, Chung HC, Salman P, Oh SC, Bodoky G, Kurteva G, Volovat C, Moiseyenko VM, Gorbunova V, Park JO, Sawaki A, Celik I, Gotte H, Melezinkova H, Moehler M: Capecitabine and cisplatin with or without cetuximab for patients with previously untreated advanced gastric cancer (EXPAND): a randomised, open-label phase 3 trial. Lancet Oncol 2013;14:490-499.

10 Ralph C, Elkord E, Burt DJ, O'Dwyer JF, Austin EB, Stern PL, Hawkins RE, Thistlethwaite FC: Modulation of lymphocyte regulation for cancer therapy: a phase II trial of tremelimumab in advanced gastric and esophageal adenocarcinoma. Clin Cancer Res 2010;16: 1662-1672.

11 Muro K, Chung HC, Shankaran V, Geva R, Catenacci D, Gupta S, Eder JP, Golan T, Le DT, Burtness B, McRee AJ, Lin CC, Pathiraja K, Lunceford J, Emancipator K, Juco J, Koshiji M, Bang YJ: Pembrolizumab for patients with PD-L1-positive advanced gastric cancer (KEYNOTE-012): a multicentre, open-label, phase 1b trial. Lancet Oncol 2016;17:717-726.

12 Alsina M, Moehler M, Hierro C, Guardeno R, Tabernero J: Immunotherapy for gastric cancer: a focus on immune checkpoints. Target Oncol 2016;11:469-477.

13 Silva R, Gullo I, Carneiro F: The PD-1:PD-L1 immune inhibitory checkpoint in Helicobacter pylori infection and gastric cancer: a comprehensive review and future perspectives. Porto Biomed J 2016;1:4-11.

14 Lauren P: The two histological main types of gastric carcinoma: diffuse and so-called intestinal-type carcinoma: an attempt at a histoclinical classification. Acta Pathol Microbiol Scand 1965;64:31-49.

15 Nakamura K, Sugano H, Takagi K: Carcinoma of the stomach in incipient phase: its histogenesis and histological appearances. Gan 1968;59:251-258.

16 Ming SC: Gastric carcinoma: a pathobiological classification. Cancer 1977;39:2475-2485.

17 Goseki N, Takizawa T, Koike M: Differences in the mode of the extension of gastric cancer classified by histological type: new histological classification of gastric carcinoma. Gut 1992;33:606-612.

18 Carneiro F, Seixas M, Sobrinho-Simoes M: New elements for an updated classification of the carcinomas of the stomach. Pathol Res Pract 1995;191:571-584.

19 Solcia E, Klersy C, Mastracci L, Alberizzi P, Candusso ME, Diegoli M, Tava F, Riboni R, Manca R, Luinetti O: A combined histologic and molecular approach identifies three groups of gastric cancer with different prognosis. Virchows Arch 2009;455:197-211.
20 Bosman FT, Carneiro F, Hruban RH, Theise ND: WHO Classification of Tumours of the Digestive System, ed 4. Lyon, IARC, 2010.

21 Japanese Gastric Cancer Association: Japanese classification of gastric carcinoma: 3rd English edition. Gastric Cancer 2011;14:101112 .

22 Carneiro F, Oliveira C, Leite M, Seruca R: Molecular targets and biological modifiers in gastric cancer. Semin Diagn Pathol 2008;25:274287.

23 Carneiro F, Grabsch HI: Pathogenesis of gastric cancer; in Hochwald SN, Kukar M (eds): Minimally Invasive Foregut Surgery for Malignancy: Principles and Practice. Cham, Springer, 2015, pp 61-72.

24 Qiu MZ, Cai MY, Zhang DS, Wang ZQ, Wang DS, Li YH, Xu RH: Clinicopathological characteristics and prognostic analysis of Lauren classification in gastric adenocarcinoma in China. J Transl Med 2013;11:58

25 Chen YC, Fang WL, Wang RF, Liu CA, Yang MH, Lo SS, Wu CW, Li AF, Shyr YM, Huang $\mathrm{KH}$ : Clinicopathological variation of Lauren classification in gastric cancer. Pathol Oncol Res 2016;22:197-202.

26 Liu L, Wang ZW, Ji J, Zhang JN, Yan M, Zhang J, Liu BY, Zhu ZG, Yu YY: A cohort study and meta-analysis between histopathological classification and prognosis of gastric carcinoma. Anticancer Agents Med Chem 2013;13:227-234.

27 Shimizu H, Ichikawa D, Komatsu S, Okamoto K, Shiozaki A, Fujiwara H, Murayama Y, Kuriu Y, Ikoma H, Nakanishi M, Ochiai T, Kokuba Y, Kishimoto M, Yanagisawa A, Otsuji E: The decision criterion of histological mixed type in "T1/T2" gastric carcinoma comparison between TNM classification and Japanese Classification of Gastric Cancer. J Surg Oncol 2012;105:800-804

28 Hanaoka N, Tanabe S, Mikami T, Okayasu I, Saigenji K: Mixed-histologic-type submucosal invasive gastric cancer as a risk factor for lymph node metastasis: feasibility of endoscopic submucosal dissection. Endoscopy 2009;41:427-432.

29 Min BH, Kim KM, Park CK, Lee JH, Rhee PL, Rhee JC, Kim JJ: Outcomes of endoscopic submucosal dissection for differentiatedtype early gastric cancer with histological heterogeneity. Gastric Cancer 2015; 18:618626.

30 Zheng HC, Li XH, Hara T, Masuda S, Yang $\mathrm{XH}$, Guan YF, Takano Y: Mixed-type gastric carcinomas exhibit more aggressive features and indicate the histogenesis of carcinomas. Virchows Arch 2008;452:525-534.

31 Park HK, Lee KY, Yoo MW, Hwang TS, Han HS: Mixed carcinoma as an independent prognostic factor in submucosal invasive gastric carcinoma. J Korean Med Sci 2016;31: 866-872.

32 Carneiro F: Classification of gastric carcinomas. Curr Diagn Pathol 1997;4:51-59. 
33 van der Post RS, Vogelaar IP, Carneiro F, et al: Hereditary diffuse gastric cancer: updated clinical guidelines with an emphasis on germline $\mathrm{CDH} 1$ mutation carriers. J Med Genet 2015;52:361-374.

34 Guilford P, Hopkins J, Harraway J, McLeod M, McLeod N, Harawira P, Taite H, Scoular $\mathrm{R}$, Miller A, Reeve AE: E-cadherin germline mutations in familial gastric cancer. Nature 1998;392:402-405.

35 Hansford S, Kaurah P, Li-Chang H, et al: Hereditary diffuse gastric cancer syndrome: $\mathrm{CDH} 1$ mutations and beyond. JAMA Oncol 2015;1:23-32.

36 Majewski IJ, Kluijt I, Cats A, Scerri TS, de Jong D, Kluin RJ, Hansford S, Hogervorst FB, Bosma AJ, Hofland I, Winter M, Huntsman D, Jonkers J, Bahlo M, Bernards R: An a-Ecatenin (CTNNA1) mutation in hereditary diffuse gastric cancer. J Pathol 2013;229:621629.

37 Huntsman DG, Carneiro F, Lewis FR, MacLeod PM, Hayashi A, Monaghan KG, Maung R, Seruca R, Jackson CE, Caldas C: Early gastric cancer in young, asymptomatic carriers of germ-line E-cadherin mutations. N Engl J Med 2001;344:1904-1909.

38 Carneiro F, Huntsman DG, Smyrk TC, Owen DA, Seruca R, Pharoah P, Caldas C, Sobrinho-Simoes M: Model of the early development of diffuse gastric cancer in E-cadherin mutation carriers and its implications for $\mathrm{pa}$ tient screening. J Pathol 2004;203:681-687.

39 van der Post RS, Gullo I, Oliveira C, Tang LH, Grabsch HI, O’Donovan M, Fitzgerald RC, van Krieken H, Carneiro F: Histopathological, molecular, and genetic profile of hereditary diffuse gastric cancer: current knowledge and challenges for the future. Adv Exp Med Biol 2016;908:371-391.

40 Songun I, van de Velde CJ, Arends JW, Blok P, Grond AJ, Offerhaus GJ, Hermans J, van Krieken JH: Classification of gastric carcinoma using the Goseki system provides prognostic information additional to TNM staging. Cancer 1999;85:2114-2118.

41 Martin IG, Dixon MF, Sue-Ling H, Axon AT, Johnston D: Goseki histological grading of gastric cancer is an important predictor of outcome. Gut 1994;35:758-763.

42 Chiaravalli AM, Klersy C, Vanoli A, Ferretti A, Capella C, Solcia E: Histotype-based prognostic classification of gastric cancer. World J Gastroenterol 2012;18:896-904.

43 Shiroshita $\mathrm{H}$, Watanabe $\mathrm{H}$, Ajioka $\mathrm{Y}$, Watanabe G, Nishikura K, Kitano S: Re-evaluation of mucin phenotypes of gastric minute welldifferentiated-type adenocarcinomas using a series of HGM, MUC5AC, MUC6, MGGMC, MUC2 and CD10 stains. Pathol Int 2004;54:311-321.

44 Kushima R, Vieth M, Borchard F, Stolte M, Mukaisho K, Hattori T: Gastric-type welldifferentiated adenocarcinoma and pyloric gland adenoma of the stomach. Gastric Cancer 2006;9:177-184.
45 Kim DH, Shin N, Kim GH, Song GA, Jeon TY, Kim DH, Lauwers GY, Park DY: Mucin expression in gastric cancer: reappraisal of its clinicopathologic and prognostic significance. Arch Pathol Lab Med 2013;137:10471053.

46 Machado JC, Nogueira AM, Carneiro F, Reis CA, Sobrinho-Simoes M: Gastric carcinoma exhibits distinct types of cell differentiation: an immunohistochemical study of trefoil peptides (TFF1 and TFF2) and mucins (MUC1, MUC2, MUC5AC, and MUC6). J Pathol 2000;190:437-443.

47 Valente P, Garrido M, Gullo I, Baldaia H, Marques M, Baldaque-Silva F, Lopes J, Carneiro F: Epithelial dysplasia of the stomach with gastric immunophenotype shows features of biological aggressiveness. Gastric Cancer 2015;18:720-728.

48 Setia N, Lauwers GY: Gastric dysplasia: update and practical approach. Diagn Histopathol 2015;21:312-322.

49 Tsukashita S, Kushima R, Bamba M, Sugihara $\mathrm{H}$, Hattori T: MUC gene expression and histogenesis of adenocarcinoma of the stomach. Int J Cancer 2001;94:166-170.

50 Takami H, Sentani K, Matsuda M, Oue N, Sakamoto N, Yasui W: Cytokeratin expression profiling in gastric carcinoma: clinicopathologic significance and comparison with tumor-associated molecules. Pathobiology 2012; 79:154-161

51 Oue N, Sentani K, Sakamoto N, Yasui W: Clinicopathologic and molecular characteristics of gastric cancer showing gastric and intestinal mucin phenotype. Cancer Sci 2015; 106:951-958.

52 Tan P, Yeoh KG: Genetics and molecular pathogenesis of gastric adenocarcinoma. Gastroenterology 2015;149:1153-1162.

53 Lei Z, Tan IB, Das K, Deng N, Zouridis H, Pattison S, Chua C, Feng Z, Guan YK, Ooi $\mathrm{CH}$, Ivanova $\mathrm{T}$, Zhang $\mathrm{S}$, Lee $\mathrm{M}$, Wu J, Ngo A, Manesh S, Tan E, Teh BT, So JB, Goh LK, Boussioutas A, Lim TK, Flotow H, Tan P, Rozen SG: Identification of molecular subtypes of gastric cancer with different responses to PI3-kinase inhibitors and 5-fluorouracil. Gastroenterology 2013;145:554-565.

54 Cancer Genome Atlas Research Network; Bass AJ, Thorsson V, Shmulevich I, et al: Comprehensive molecular characterization of gastric adenocarcinoma. Nature 2014;513: 202-209.

55 Cristescu R, Lee J, Nebozhyn M, Kim KM, Ting JC, Wong SS, Liu J, Yue YG, Wang J, Yu K, Ye XS, Do IG, Liu S, Gong L, Fu J, Jin JG, Choi MG, Sohn TS, Lee JH, Bae JM, Kim ST, Park SH, Sohn I, Jung SH, Tan P, Chen R, Hardwick J, Kang WK, Ayers M, Hongyue D, Reinhard C, Loboda A, Kim S, Aggarwal A: Molecular analysis of gastric cancer identifies subtypes associated with distinct clinical outcomes. Nat Med 2015;21:449-456.
56 Das K, Chan XB, Epstein D, Teh BT, Kim K-M, Kim ST, Park SH, Kang WK, Rozen S, Lee J, Tan P: NanoString expression profiling identifies candidate biomarkers of RAD001 response in metastatic gastric cancer. ESMO Open 2016;1:e000009.

57 Kaneda A, Matsusaka K, Aburatani H, Fukayama M: Epstein-Barr virus infection as an epigenetic driver of tumorigenesis. Cancer Res 2012;72:3445-3450.

58 Wang K, Yuen ST, Xu J, Lee SP, Yan HH, Shi ST, Siu HC, Deng S, Chu KM, Law S, Chan KH, Chan AS, Tsui WY, Ho SL, Chan AK, Man JL, Foglizzo V, Ng MK, Chan AS, Ching YP, Cheng GH, Xie T, Fernandez J, Li VS, Clevers $H$, Rejto PA, Mao M, Leung SY: Wholegenome sequencing and comprehensive molecular profiling identify new driver mutations in gastric cancer. Nat Genet 2014;46: 573-582.

59 Kakiuchi M, Nishizawa T, Ueda H, Gotoh K, Tanaka A, Hayashi A, Yamamoto S, Tatsuno K, Katoh H, Watanabe Y, Ichimura T, Ushiku T, Funahashi S, Tateishi K, Wada I, Shimizu N, Nomura S, Koike K, Seto Y, Fukayama M, Aburatani H, Ishikawa S: Recurrent gain-offunction mutations of RHOA in diffuse-type gastric carcinoma. Nat Genet 2014;46:583587.

60 Lee YS, Cho YS, Lee GK, Lee S, Kim YW, Jho S, Kim HM, Hong SH, Hwang JA, Kim SY, Hong D, Choi IJ, Kim BC, Kim BC, Kim CH, Choi H, Kim Y, Kim KW, Kong G, Kim HL, Bhak J, Lee SH, Lee JS: Genomic profile analysis of diffuse-type gastric cancers. Genome Biol 2014;15:R55.

61 Wang HH, Wu MS, Shun CT, Wang HP, Lin CC, Lin JT: Lymphoepithelioma-like carcinoma of the stomach: a subset of gastric carcinoma with distinct clinicopathological features and high prevalence of Epstein-Barr virus infection. Hepatogastroenterology 1999; 46:1214-1219.

62 Park S, Choi MG, Kim KM, Kim HS, Jung SH, Lee JH, Noh JH, Sohn TS, Bae JM, Kim S: Lymphoepithelioma-like carcinoma: a distinct type of gastric cancer. J Surg Res 2015; 194:458-463.

63 Lim H, Park YS, Lee JH, Son da H, Ahn JY, Choi KS, Kim do H, Choi KD, Song HJ, Lee GH, Jung HY, Kim JH, Yook JH, Kim BS: Features of gastric carcinoma with lymphoid stroma associated with Epstein-Barr virus. Clin Gastroenterol Hepatol 2015;13:17381744.e1732.

64 Grogg KL, Lohse CM, Pankratz VS, Halling KC, Smyrk TC: Lymphocyte-rich gastric cancer: associations with Epstein-Barr virus, microsatellite instability, histology, and survival. Modern Pathol 2003;16:641-651.

65 Lu BJ, Lai M, Cheng L, Xu JY, Huang Q: Gastric medullary carcinoma, a distinct entity associated with microsatellite instability- $\mathrm{H}$, prominent intraepithelial lymphocytes and improved prognosis. Histopathology 2004; 45:485-492. 
66 Le DT, Uram JN, Wang H, Bartlett BR, Kemberling $\mathrm{H}$, Eyring $\mathrm{AD}$, Skora $\mathrm{AD}$, Luber BS, Azad NS, Laheru D, Biedrzycki B, Donehower RC, Zaheer A, Fisher GA, Crocenzi TS, Lee JJ, Duffy SM, Goldberg RM, de la Chapelle A, Koshiji M, Bhaijee F, Huebner T, Hruban RH, Wood LD, Cuka N, Pardoll DM, Papadopoulos N, Kinzler KW, Zhou S, Cornish TC, Taube JM, Anders RA, Eshleman JR, Vogelstein B, Diaz LA Jr: PD-1 blockade in tumors with mismatch-repair deficiency. N Engl J Med 2015;372:2509-2520.

67 Li Z, Lai Y, Sun L, Zhang X, Liu R, Feng G, Zhou L, Jia L, Huang X, Kang Q, Lin D, Gao J, Shen $\mathrm{L}$ : PD-L1 expression is associated with massive lymphocyte infiltration and histology in gastric cancer. Hum Pathol 2016;55:182-189.

68 Thompson ED, Zahurak M, Murphy A, Cornish T, Cuka N, Abdelfatah E, Yang S, Duncan M, Ahuja N, Taube JM, Anders RA, Kelly RJ: Patterns of PD-L1 expression and CD8 T cell infiltration in gastric adenocarcinomas and associated immune stroma. Gut 2017;66: 794-801.

69 Kawazoe A, Kuwata T, Kuboki Y, Shitara K, Nagatsuma AK, Aizawa M, Yoshino T, Doi T, Ohtsu A, Ochiai A: Clinicopathological features of programmed death ligand 1 expression with tumor-infiltrating lymphocyte, mismatch repair, and Epstein-Barr virus status in a large cohort of gastric cancer patients. Gastric Cancer 2017;20:407-415.

70 Gullo I, Gonçalves G, Pinto ML, Almeida GM, Oliveira C, Carneiro F: Gastric carcinoma with lymphoid stroma: a study of EpsteinBarr virus, microsatellite instability, tumour immune microenvironment and PD-L1 expression. Virchows Arch 2016;469(suppl 1):S3-S4.

71 Derks S, Liao X, Chiaravalli AM, Xu X, Camargo MC, Solcia E, Sessa F, Fleitas T, Freeman GJ, Rodig SJ, Rabkin CS, Bass AJ: Abundant PD-L1 expression in Epstein-Barr virusinfected gastric cancers. Oncotarget 2016;7: 32925-32932.

72 Boger C, Behrens HM, Mathiak M, Kruger S, Kalthoff H, Rocken C: PD-L1 is an independent prognostic predictor in gastric cancer of Western patients. Oncotarget 2016;7:2426924283.

73 Dong M, Wang HY, Zhao XX, Chen JN, Zhang YW, Huang Y, Xue L, Li HG, Du H, $\mathrm{Wu} \mathrm{XY}$, Shao CK: Expression and prognostic roles of PIK3CA, JAK2, PD-L1, and PD-L2 in Epstein-Barr virus-associated gastric carcinoma. Hum Pathol 2016;53:25-34.

74 Ma C, Patel K, Singhi AD, Ren B, Zhu B, Shaikh F, Sun W: Programmed death-ligand 1 expression is common in gastric cancer associated with Epstein-Barr virus or microsatellite instability. Am J Surg Pathol 2016;40: 1496-1506.

$75 \mathrm{Kim} \mathrm{H}$, An JY, Noh SH, Shin SK, Lee YC, Kim $\mathrm{H}$ : High microsatellite instability predicts good prognosis in intestinal-type gastric cancers. J Gastroenterol Hepatol 2011;26:585592.
76 Deng N, Goh LK, Wang H, Das K, Tao J, Tan IB, Zhang S, Lee M, Wu J, Lim KH, Lei Z, Goh G, Lim QY, Tan AL, Sin Poh DY, Riahi S, Bell S, Shi MM, Linnartz R, Zhu F, Yeoh KG, Toh HC, Yong WP, Cheong HC, Rha SY, Boussioutas A, Grabsch H, Rozen S, Tan P: A comprehensive survey of genomic alterations in gastric cancer reveals systematic patterns of molecular exclusivity and co-occurrence among distinct therapeutic targets. Gut 2012; 61:673-684.

77 Wong H, Yau T: Molecular targeted therapies in advanced gastric cancer: does tumor histology matter? Therap Adv Gastroenterol 2013; 6:15-31.

78 Speck O, Tang W, Morgan DR, Kuan PF, Meyers MO, Dominguez RL, Martinez E, Gulley ML: Three molecular subtypes of gastric adenocarcinoma have distinct histochemical features reflecting Epstein-Barr virus infection status and neuroendocrine differentiation. Appl Immunohistochem Mol Morphol 2015;23:633-645.

79 Mafficini A, Amato E, Fassan M, Simbolo M, Antonello D, Vicentini C, Scardoni M, Bersani S, Gottardi M, Rusev B, Malpeli G, Corbo V, Barbi S, Sikora KO, Lawlor RT, Tortora G, Scarpa A: Reporting tumor molecular heterogeneity in histopathological diagnosis. PLoS One 2014;9:e104979.

80 Setia N, Agoston AT, Han HS, Mullen JT, Duda DG, Clark JW, Deshpande V, MinoKenudson M, Srivastava A, Lennerz JK, Hong TS, Kwak EL, Lauwers GY: A protein and mRNA expression-based classification of gastric cancer. Modern Pathol 2016;29:772-784.

81 Bedard PL, Hansen AR, Ratain MJ, Siu LL: Tumour heterogeneity in the clinic. Nature 2013;501:355-364.

82 Klein CA: Selection and adaptation during metastatic cancer progression. Nature 2013; 501:365-372.

83 Gerlinger M, Rowan AJ, Horswell S, Larkin J, Endesfelder D, Gronroos E, Martinez P, Matthews N, Stewart A, Tarpey P, Varela I, Phillimore B, Begum S, McDonald NQ, Butler A, Jones D, Raine K, Latimer C, Santos CR, Nohadani M, Eklund AC, Spencer-Dene B, Clark G, Pickering L, Stamp G, Gore M, Szallasi Z, Downward J, Futreal PA, Swanton C: Intratumor heterogeneity and branched evolution revealed by multiregion sequencing. $\mathrm{N}$ Engl J Med 2012;366:883-892.

84 Meric-Bernstam F, Mills GB: Overcoming implementation challenges of personalized cancer therapy. Nat Rev Clin Oncol 2012;9: 542-548.

85 Ryska A: Molecular pathology in real time. Cancer Metastasis Rev 2016;35:129-140.

86 Stelzner S, Emmrich P: The mixed type in Laurén's classification of gastric carcinoma: histologic description and biologic behavior. Gen Diagn Pathol 1997;143:39-48.
87 Joo M, Kim KM: Histologic discrepancy between gastric biopsy and resection specimen in the era of endoscopic treatment for early gastric cancer (in Korean). Korean J Gastroenterol 2014;64:256-259.

88 Machado JC, Soares P, Carneiro F, Rocha A, Beck S, Blin N, Berx G, Sobrinho-Simoes M: $\mathrm{E}$-cadherin gene mutations provide a genetic basis for the phenotypic divergence of mixed gastric carcinomas. Lab Invest 1999;79:459465.

89 Kozuki T, Yao T, Nakamura S, Matsumoto T, Tsuneyoshi M: Differences in p53 and cadherin-catenin complex expression between histological subtypes in diffusely infiltrating gastric carcinoma. Histopathology 2002;41: 56-64.

90 Carvalho B, Buffart TE, Reis RM, Mons T, Moutinho C, Silva P, van Grieken NC Grabsch H, van de Velde CJ, Ylstra B, Meijer GA, Carneiro F: Mixed gastric carcinomas show similar chromosomal aberrations in both their diffuse and glandular components. Cell Oncol 2006;28:283-294.

91 Park SY, Kook MC, Kim YW, Cho NY, Kim TY, Kang GH: Mixed-type gastric cancer and its association with high-frequency $\mathrm{CpG}$ island hypermethylation. Virchows Arch 2010 456:625-633.

92 Hudis CA: Trastuzumab - mechanism of action and use in clinical practice. $\mathrm{N}$ Engl J Med 2007;357:39-51.

93 Gravalos C, Jimeno A: HER2 in gastric cancer: a new prognostic factor and a novel therapeutic target. Ann Oncol 2008;19:15231529.

94 Hofmann M, Stoss O, Shi D, Buttner R, van de Vijver M, Kim W, Ochiai A, Ruschoff J, Henkel T: Assessment of a HER2 scoring system for gastric cancer: results from a validation study. Histopathology 2008;52:797-805.

95 van Cutsem E, Bang YJ, Feng-Yi F, Xu JM, Lee KW, Jiao SC, Chong JL, Lopez-Sanchez RI, Price T, Gladkov O, Stoss O, Hill J, Ng V, Lehle M, Thomas M, Kiermaier A, Ruschoff J: HER2 screening data from ToGA: targeting HER2 in gastric and gastroesophageal junction cancer. Gastric Cancer 2015;18:476-484.

96 Tafe LJ, Janjigian YY, Zaidinski M, Hedvat CV, Hameed MR, Tang LH, Hicks JB, Shah MA, Barbashina V: Human epidermal growth factor receptor 2 testing in gastroesophageal cancer: correlation between immunohistochemistry and fluorescence in situ hybridization. Arch Pathol Lab Med 2011;135:1460-1465.

97 Zhang XL, Yang YS, Xu DP, Qu JH, Guo MZ, Gong Y, Huang J: Comparative study on overexpression of HER2/neu and HER3 in gastric cancer. World J Surg 2009;33:21122118.

98 Begnami MD, Fukuda E, Fregnani JH, Nonogaki S, Montagnini AL, da Costa WL Jr, Soares FA: Prognostic implications of altered human epidermal growth factor receptors (HERs) in gastric carcinomas: HER2 and HER3 are predictors of poor outcome. J Clin Oncol 2011;29:3030-3036. 
99 Nagatsuma AK, Aizawa M, Kuwata T, Doi T, Ohtsu A, Fujii H, Ochiai A: Expression profiles of HER2, EGFR, MET and FGFR2 in a large cohort of patients with gastric adenocarcinoma. Gastric Cancer 2015;18:227238.

100 Duraes C, Almeida GM, Seruca R, Oliveira C, Carneiro F: Biomarkers for gastric cancer: prognostic, predictive or targets of therapy? Virchows Arch 2014;464:367-378.

101 Ma J, Shen H, Kapesa L, Zeng S: Lauren classification and individualized chemotherapy in gastric cancer. Oncol Lett 2016;11:29592964.

102 Park DI, Yun JW, Park JH, Oh SJ, Kim HJ, Cho YK, Sohn CI, Jeon WK, Kim BI, Yoo $\mathrm{CH}$, Son $\mathrm{BH}$, Cho EY, Chae SW, Kim EJ, Sohn JH, Ryu SH, Sepulveda AR: HER-2/ neu amplification is an independent prognostic factor in gastric cancer. Dig Dis Sci 2006;51:1371-1379.

103 Janjigian YY, Werner D, Pauligk C, Steinmetz K, Kelsen DP, Jager E, Altmannsberger HM, Robinson E, Tafe LJ, Tang LH, Shah MA, Al-Batran SE: Prognosis of metastatic gastric and gastroesophageal junction cancer by HER 2 status: a European and USA International collaborative analysis. Ann Oncol 2012;23:2656-2662.

104 Sornmayura P, Rerkamnuaychoke B, Jinawath A, Euanorasetr C: Human epidermal growth-factor receptor 2 overexpression in gastric carcinoma in Thai patients. J Med Assoc Thai 2012;95:88-95.

105 Kataoka Y, Okabe H, Yoshizawa A, Minamiguchi S, Yoshimura K, Haga H, Sakai Y: HER2 expression and its clinicopathological features in resectable gastric cancer. Gastric Cancer 2013;16:84-93.

106 Grabsch H, Sivakumar S, Gray S, Gabbert HE, Muller W: HER2 expression in gastric cancer: rare, heterogeneous and of no prognostic value - conclusions from 924 cases of two independent series. Cell Oncol 2010;32: 57-65.

107 Barros-Silva JD, Leitao D, Afonso L, Vieira J, Dinis-Ribeiro M, Fragoso M, Bento MJ, Santos L, Ferreira P, Rego S, Brandao C, Carneiro F, Lopes C, Schmitt F, Teixeira MR: Association of ERBB2 gene status with histopathological parameters and disease-specific survival in gastric carcinoma patients. Br J Cancer 2009;100:487-493.

108 Wu MS, Shun CT, Wang HP, Sheu JC, Lee WJ, Wang TH, Lin JT: Genetic alterations in gastric cancer: relation to histological subtypes, tumor stage, and Helicobacter pylori infection. Gastroenterology 1997;112:14571465.

109 Varis A, Zaika A, Puolakkainen P, Nagy B, Madrigal I, Kokkola A, Vayrynen A, Karkkainen P, Moskaluk C, El-Rifai W, Knuutila $S$ : Coamplified and overexpressed genes at $E R B B 2$ locus in gastric cancer. Int J Cancer 2004;109:548-553.
110 Tanner M, Hollmen M, Junttila TT, Kapanen AI, Tommola S, Soini Y, Helin H, Salo J, Joensuu H, Sihvo E, Elenius K, Isola J: Amplification of HER-2 in gastric carcinoma: association with Topoisomerase II $\alpha$ gene amplification, intestinal type, poor prognosis and sensitivity to trastuzumab. Ann Oncol 2005; 16:273-278.

111 Grillo F, Fassan M, Ceccaroli C, Giacometti C, Curto M, Zagonel V, Ceppa P, Nitti D, Castoro C, Fiocca R, Rugge M, Mastracci L: The reliability of endoscopic biopsies in assessing HER2 status in gastric and gastroesophageal junction cancer: a study comparing biopsies with surgical samples. Transl Oncol 2013;6:10-16.

112 Lin JT, Wu MS, Shun CT, Lee WJ, Sheu JC, Wang TH: Occurrence of microsatellite instability in gastric carcinoma is associated with enhanced expression of erbB-2 oncoprotein. Cancer Res 1995;55:1428-1430.

113 Lee S, de Boer WB, Fermoyle S, Platten M, Kumarasinghe MP: Human epidermal growth factor receptor 2 testing in gastric carcinoma: issues related to heterogeneity in biopsies and resections. Histopathology 2011;59:832-840.

114 Lee HE, Park KU, Yoo SB, Nam SK, Park DJ, Kim HH, Lee HS: Clinical significance of intratumoral HER2 heterogeneity in gastric cancer. Eur J Cancer (Oxford) 2013;49: 1448-1457.

115 Kanayama K, Imai H, Yoneda M, Hirokawa YS, Shiraishi T: Significant intratumoral heterogeneity of human epidermal growth factor receptor 2 status in gastric cancer: a comparative study of immunohistochemistry, FISH, and dual-color in situ hybridization. Cancer Sci 2016;107:536-542.

116 Yang J, Luo H, Li Y, Li J, Cai Z, Su X, Dai D, $\mathrm{Du}$ W, Chen T, Chen M: Intratumoral heterogeneity determines discordant results of diagnostic tests for human epidermal growth factor receptor (HER) 2 in gastric cancer specimens. Cell Biochem Biophys 2012;62: 221-228.

117 Grillo F, Fassan M, Sarocchi F, Fiocca R, Mastracci L: HER2 heterogeneity in gastric/ gastroesophageal cancers: from benchside to practice. World J Gastroenterol 2016;22: 5879-5887.

118 Tominaga N, Gotoda T, Hara M, Hale MD, Tsuchiya T, Matsubayashi J, Kono S, Kusano C, Itoi T, Fujimoto K, Moriyasu F, Grabsch HI: Five biopsy specimens from the proximal part of the tumor reliably determine HER2 protein expression status in gastric cancer. Gastric Cancer 2016;19:553-560.

119 Selcukbiricik F, Erdamar S, Buyukunal E, Serrdengecti S, Demirelli F: Is her-2 status in the primary tumor correlated with matched lymph node metastases in patients with gastric cancer undergoing curative gastrectomy? Asian Pac J Cancer Prev 2014;15: 10607-10611.
120 Fassan M, Ludwig K, Pizzi M, Castoro C, Guzzardo V, Balistreri M, Zaninotto G, Ruol A, Giacomelli L, Ancona E, Rugge M: Human epithelial growth factor receptor 2 (HER2) status in primary and metastatic esophagogastric junction adenocarcinomas. Hum Pathol 2012;43:1206-1212.

121 Kim MA, Lee HJ, Yang HK, Bang YJ, Kim WH: Heterogeneous amplification of ERBB2 in primary lesions is responsible for the discordant ERBB2 status of primary and metastatic lesions in gastric carcinoma. Histopathology 2011;59:822-831.

122 Gumusay O, Benekli M, Ekinci O, Baykara M, Ozet A, Coskun U, Demirci U, Uner A, Dursun A, Atak EY, Buyukberber S: Discordances in HER2 status between primary gastric cancer and corresponding metastatic sites. Jpn J Clin Oncol 2015;45:416-421.

123 Bozzetti C, Negri FV, Lagrasta CA, Crafa P, Bassano C, Tamagnini I, Gardini G, Nizzoli R, Leonardi F, Gasparro D, Camisa R, Cavalli S, Silini EM, Ardizzoni A: Comparison of HER2 status in primary and paired metastatic sites of gastric carcinoma. Br J Cancer 2011;104:1372-1376.

124 Ruschoff J, Dietel M, Baretton G, Arbogast S, Walch A, Monges G, Chenard MP, Penault-Llorca F, Nagelmeier I, Schlake W, Hofler H, Kreipe HH: HER2 diagnostics in gastric cancer-guideline validation and development of standardized immunohistochemical testing. Virchows Arch 2010;457: 299-307.

125 Chen C, Yang JM, Hu TT, Xu TJ, Yan G, Hu SL, Wei W, Xu WP: Prognostic role of human epidermal growth factor receptor in gastric cancer: a systematic review and metaanalysis. Arch Med Res 2013;44:380-389.

$126 \mathrm{Gu}$ J, Zheng L, Wang Y, Zhu M, Wang Q, Li $\mathrm{X}$ : Prognostic significance of HER2 expression based on trastuzumab for gastric cancer (ToGA) criteria in gastric cancer: an updated meta-analysis. Tumour Biol 2014;35. 5315-5321.

127 Kim MA, Jung EJ, Lee HS, Lee HE, Jeon YK, Yang HK, Kim WH: Evaluation of HER-2 gene status in gastric carcinoma using immunohistochemistry, fluorescence in situ hybridization, and real-time quantitative polymerase chain reaction. Hum Pathol 2007;38:1386-1393.

128 Cho EY, Park K, Do I, Cho J, Kim J, Lee J, Kim S, Kim KM, Sohn TS, Kang WK, Kim $S$ : Heterogeneity of ERBB2 in gastric carcinomas: a study of tissue microarray and matched primary and metastatic carcinomas. Mod Pathol 2013;26:677-684.

129 Terashima M, Kitada K, Ochiai A, Ichikawa W, Kurahashi I, Sakuramoto S, Katai H, Sano T, Imamura H, Sasako M: Impact of expression of human epidermal growth factor receptors EGFR and ERBB2 on survival in stage II/III gastric cancer. Clin Cancer Res 2012;18:5992-6000. 
130 Ruschoff J, Hanna W, Bilous M, Hofmann M, Osamura RY, Penault-Llorca F, van de Vijver M, Viale G: HER2 testing in gastric cancer: a practical approach. Mod Pathol 2012;25:637-650.

131 Asioli S, Maletta F, Verdun di Cantogno L, Satolli MA, Schena M, Pecchioni C, Botta C, Chiusa L, Molinaro L, Conti L, Viale G, Ingravallo G, Maiorano E, Sapino A: Approaching heterogeneity of human epidermal growth factor receptor 2 in surgical specimens of gastric cancer. Hum Pathol 2012;43:2070-2079.
132 Ge X, Wang H, Zeng H, Jin X, Sujie A, Xu C, Liu Y, Huang J, Ji Y, Tan Y, Liu T, Hou Y, Qin J, Sun Y, Qin X: Clinical significance of assessing Her2/neu expression in gastric cancer with dual tumor tissue paraffin blocks. Hum Pathol 2015;46:850-857.

133 Wang T, Hsieh ET, Henry P, Hanna W, Streutker CJ, Grin A: Matched biopsy and resection specimens of gastric and gastroesophageal adenocarcinoma show high concordance in HER2 status. Hum Pathol 2014; 45:970-975.

134 Pirrelli M, Caruso ML, Di Maggio M, Armentano R, Valentini AM: Are biopsy specimens predictive of HER2 status in gastric cancer patients? Dig Dis Sci 2013;58:397404.
135 Gullo I, Grillo F, Molinaro L, Fassan M, De Silvestri A, Tinelli C, Rugge M, Fiocca R, Mastracci L: Minimum biopsy set for HER2 evaluation in gastric and gastro-esophageal junction cancer. Endosc Int Open 2015; 3:E165-E170

136 Ahn S, Ahn S, van Vrancken M, Lee M, Ha SY, Lee H, Min BH, Lee JH, Kim JJ, Choi S, Jung SH, Choi MG, Lee JH, Sohn TS, Bae JM, Kim S, Kim KM: Ideal number of biopsy tumor fragments for predicting HER2 status in gastric carcinoma resection specimens. Oncotarget 2015;6:38372-38380. 